\title{
COUCHSURFING AS A MODERN WAY OF DESTINATION EXPLORING
}

\author{
Jovana Miljković \\ Tamara Božović \\ Ivan Čapeta
}

https://doi.org//10.20867/tosee.06.30

\begin{abstract}
Purpose - The accelerated lifestyle has led to changes in the way of traveling. The development of technology and the internet has created the opportunity for online contact with people from all over the world, so we can say that traveling has not been this easy and affordable so far. People choose shorter trips, meet the locals, learn about their culture and customs. The paper looks for the benefits of using the Couchsurfing network and its aim is to present the motivation of respondents from former Yugoslav countries to use the network during travel, as well as to host travelers at home.

Methodology - The questions for the questionnaire were acquired from the research done by Liu (2012), while the authors entered the offered answers based on a review of the Couchsurfing.com site. Couchsurfing users received online questionnaires via private message and through groups. The questionnaire was also sent through Facebook private messages and posted in private groups. Findings - Based on the results, it is concluded that the dominant motive for using Couchsurfing during the trip is to get to know the local population, culture and customs, as well as hosting and keeping company to travelers visiting this region.

Contribution - The social contribution of this paper emphasizes the motives of the Couchsurfing users from the former Yugoslav countries for traveling and hosting travelers. New research can be expanded to the level of Europe or separated for the mentioned countries.
\end{abstract}

Keywords: Couchsurfing; Cultural exchange, Slow tourism, Couchsurfing trust, Travel, Balkans.

\section{INTRODUCTION}

Lifestyle changes and an accelerated pace require turning to new types of tourism. The development of technology and the Internet usage in everyday life are changing the traditional way of traveling. There is an emphasis on the need for shorter trips, weekend trips, and excursions. Some tourists are choosing experiencing the life as a local by integration in the local community customs and first-hand experiences. Is there a better way to see the city than to walk with locals, sleep at their home, share a meal with them and meet their friends, even for a couple of days? One network is making all of this possible. Couchsurfing is an online hospitality exchange service founded in 2004, which became an ongoing global trend in the tourism industry in the last decade.

Couchsurfing is a travel-oriented network where members offer free accommodation, company, traveling tips and member gatherings. It has been the subject of study by many authors for years. From the concept of the network, the development of personal profiles, all the way up to gaining trust in the person to whom we open the door of our home or where we go to visit, Couchsurfing has indeed turned to a specific theme (eg, Bialski and 
ToSEE - Tourism in Southern and Eastern Europe, Vol. 6, pp. 455-466, 2021.

J. Miljković, T. Božović, I. Čapeta: COUCHSURFING AS A MODERN WAY OF DESTINATION ...

Batorski 2010; Tan 2010; Rosen et al. 2011; Skog 2012; Bialski 2012; Lipp 2012; Liu 2012; Ronzhyn and Kuznetsova 2014; Ronzhyn 2015; Chen 2018). Couchsurfing is not intended only for young people, but for anyone who supports the ideology behind the concept of this network. People from all over the world are opening their homes to strangers they met over the Couchsurfing website. It is an exchange of culture and lifestyle supported by the unique opportunity to see new places, experience and hear new things (Skog 2012).

The best way to get to know the destination is to explore it with the locals and become a part of the community, thus the subject of research is to what extent Couchsurfing users from the former Yugoslav countries are willing to use the network for travels, meet with locals, and host travelers that are exploring their ambiance. The use of Couchsurfing can also be associated with slow tourism as the motivation is similar - getting to know the culture of the local community, connecting with the place, culture, and people. The feature of slow tourism is the need to get to know one destination more deeply than more superficially (Georgica 2015). Couchsurfing is one of the ideal ways to implement this type of tourism, and for tourists to become part of the local community, at least for a short amount of time.

\section{LITERATURE OVERVIEW}

The tourism service sector is in the process of constant change. It has transformed from passive usage to more engaging service activities (Taheri et al. 2019). Following the advancements of technology and transportation, another growing trend in global tourism the physical mobility, as the remote parts of the world are now more accessible than ever (Liu 2012). Changes in the working conditions contribute to the excess of free time, which people want to use constructively. With the low-cost airline expansion, destinations are becoming easily accessible. In addition to the positive changes, unfortunate situations can occur that will affect tourism. As the Sigala (2020) affirms, the tourism industry has faced many challenges since the worldwide proclamation of the Covid-19 virus pandemic. With the crisis-caused instability, the number of travels decreased, especially when it became a health crisis (Neuburger and Egger 2020). Travelers find it safer to travel within their country than abroad (Wolf et al. 2019). With the reduced number of international travels, this period may become the opportunity for changes in the tourism industry (Sigala 2020).

Active travels and connection with the local community have a significant role in tourism. This can be most evident in slow tourism, a relatively new concept of tourism that emphasizes connecting travelers with the local population to establish a close connection and authentic experience (Dickinson and Lumsdon 2010; Fullagar et al. 2012; Germann Molz 2013). Travelers who practice this way of travel seek to privatize local culture, gastronomy, and history through communication with the local community (Gardner 2009). Many characteristics of slow tourists (slow tourism) can be associated with Couchsurfers, such as the desire for cultural exchange, connecting with the host through language learning, and trying to accomodate the authentic local experience at least for a time of the stay. 
ToSEE - Tourism in Southern and Eastern Europe, Vol. 6, pp. 455-466, 2021.

J. Miljković, T. Božović, I. Čapeta: COUCHSURFING AS A MODERN WAY OF DESTINATION ...

Germann Molz (2011) introduced the term "network hospitality" to gesture towards the way individuals imagine and perform hospitality in a mobile and networked society. The author asserts that it refers to the way Couchsurfers connect using an online networking system, and later meet offline, face-to-face. As Rosen et al. (2011) state, Couchsurfing is more than an online community used for accommodation while traveling by staying at the homes of the other members, it is a community used for exchanging information, culture, stories, and advice. Authors assert that the internet changed the traditional concept of the community and that the distinction between face-to-face and virtual is blurred. This has attracted the attention of sociologists, who are researching the Couchsurfing trend. Lipp (2012) points out that the idea of Couchsurfing as a "global community" attracts plenty of attention as a part of the Web 2.0 phenomenon. Web 2.0 or the "social web" refers to internet content in which the interaction between users is emphasized (O'Reilly 2007).

The growth of a global community is the primary use of the Couchsurfing network. To become a part of the Couchsurfing online community, a new user must create account and provide an essential information. The process of self-presentation online is almost as important as offline. Profile questions have a dual function, not only users get to know more about a person, but they also promote trust within the Couchsurfing community, contributing to the sense of familiarity. The profile is the first contact that users have (Bialski and Batorski 2010). After registering as a member, one can ask through the website for "free" accommodation from local members and stay at their home instead of booking a hostel or a hotel (Chen 2018). For some members, Couchsurfing is a lifestyle.

Bialski and Batorski (2010) consider that Couchsurfing is based on a common goal and ideology. Opening the doors of your home to travelers from all over the world can contribute to spreading cultural perspectives, education, even getting to know yourself better. In order to be able to use the Couchsurfing network while traveling, you must have the confidence in your future host. Mijatov and Pivac (2016) emphasize that this network brings certain risks, for the guest and the host equally. Only based on the internet profile we decide whether we will meet someone in person. Website provides a friendship function, where users link themselves with others and collect references from guests and hosts. This is one of the ways to gain trust online (Lipp 2012). In addition to the Friend function, Couchsurfing provides references and vouch for options, which can help gain trust in a user. References are perhaps the most suitable way to choose a host and decide whether to except a guest, as they are public and created after the host-guest arrangement and left by previous guests and hosts (Ronzhyn and Kuznetsova 2014). Despite the numerous information on user profiles, the authors point out that personal contact with strangers can be unpredictable, even though users of this network still decide to think positively (Mijatov and Pivac 2016). The authors further agree that there are many advantages to Couchsurfing, among which the economy of travel especially stands out. The economic component of Couchsurfing is the subject of research since it is based on the concept of free accommodation. Uzunca and Borlenghi (2019) study the concept of the Couchsurfing platform economy and assert that the main drivers for the Couchsurfing users are non-monetary benefits of this network such as socializing and cultural exchange. 
ToSEE - Tourism in Southern and Eastern Europe, Vol. 6, pp. 455-466, 2021.

J. Miljković, T. Božović, I. Čapeta: COUCHSURFING AS A MODERN WAY OF DESTINATION ...

\section{METHODOLOGY}

\subsection{Sample}

The data sample has been gathered from the 94 respondents. The online questionnaire consisted of 14 questions about socio-demographic and personal data, respondent online habits, and offline communication behavior. Although traveling abroad during the previous year was cut down to a minimum, or not possible at all, respondents referred to the previous experience they had gained on the Couchsurfing network. The reduced number of trips and therefore fewer active network users affected a smaller number of respondents. Socio-demographic characteristics are shown in Table 1.

Table 1: Socio-demographic characteristics of respondents $(\mathbf{n}=94)$

\begin{tabular}{lccc}
\hline Gender & Percentage $(\%)$ & Age & Percentage $(\%)$ \\
\hline Male & 43.6 & $<20$ age & 2.1 \\
Female & 56.4 & $21-30$ age & 41.5 \\
Education & Percentage $(\%)$ & $31-40$ age & 29.8 \\
Primary school & 0 & $41-50$ age & 20.2 \\
High school & 16.0 & $51-60$ age & 4.3 \\
Faculty & 41.5 & $>61$ age & 2.1 \\
Master studies & 33.0 & & \\
PhD studies & 9.6 & & \\
\hline Income & Percentage $(\%)$ & Profession & Percentage $(\%)$ \\
$<500 €$ & 35.1 & Pupil & 0 \\
$501-1000 €$ & 42.6 & The student & 17.0 \\
$1001-1500 €$ & 6.4 & Employed & 70.2 \\
$>1500 €$ & 16.0 & Unemployed & 10.6 \\
& & Retired & 2.1 \\
\hline
\end{tabular}

Source: author's work

Table 1 shows that a larger share of respondents who participated in the survey are women $(56.4 \%)$, of the age that most belongs to the category of 21-30 years $(41.5 \%)$ Additionally, the respondents are mostly highly educated and employed people $(70.2 \%)$, with the most common range of $501-1000 €(42.6 \%)$ income.

\subsection{Procedure}

The research was conducted during March and April 2021. An online (Google Docs) questionnaire was distributed via social networks (Couchsurfing, Facebook, LinkedIn) in the form of group posts and private messages. A study was conducted for respondents from the former Yugoslav countries (Serbia, Croatia, Bosnia and Herzegovina, Slovenia, Montenegro, North Macedonia). Problems in collecting responses emerged due to the crisis and the reduced number of travels, active users, and reduced activity in Couchsurfing groups. Overviewing profiles from the Balkans, plenty of people no longer 
ToSEE - Tourism in Southern and Eastern Europe, Vol. 6, pp. 455-466, 2021.

J. Miljković, T. Božović, I. Čapeta: COUCHSURFING AS A MODERN WAY OF DESTINATION ...

use their Couchsurfing profile, as there were examples where the last time the user was online was more than five, some even more than ten years ago.

\subsection{Instrument}

The questionnaire questions were acquired from the research done by the author Liu (2012). After reviewing the Couchsurfing network, the authors introduced possible answers. Some questions were of the semi-open type, and the respondents could write their answers. Data collected by the survey were processed through the program IBM SPSS 17 (descriptive statistical analysis, t-test, ANOVA test).

\section{RESULTS AND DISCUSSIONS}

Graph 1 shows the place of residence of the respondents. Most of the respondents are from Serbia (72.3\%), followed by Croatia (10.6\%), Bosnia and Herzegovina $(7.4 \%)$. Two respondents were from Slovenia, and one respondent from North Macedonia. None of the respondents were from Montenegro, and as many as six respondents did not answer in which country they live.

\section{Graph 1: Country of residence}

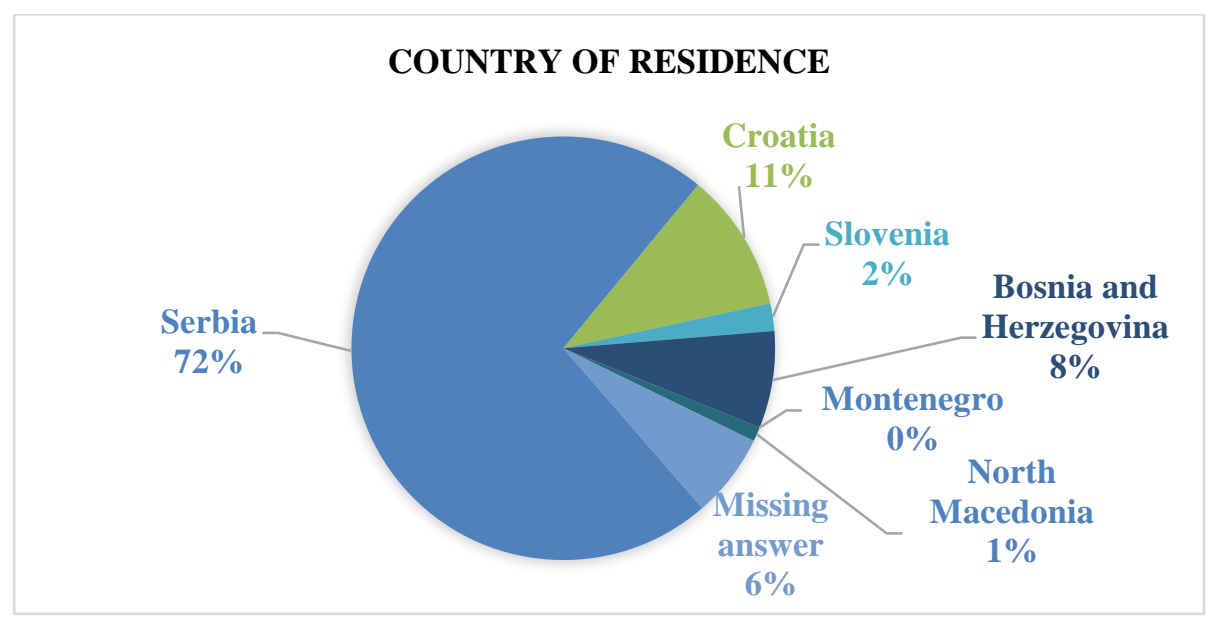

Source: author's work

Graph 2 shows the foreign languages spoken by the respondents. Respondents were able to mark several offered answers and add a additional foreign language. By reviewing the answers, all respondents are fluent in at least one foreign language, one respondent speaks as many as six foreign languages, and five speak five foreign languages. English is the most common foreign language, used by $97.9 \%$ of respondents. It is followed by German and Spanish, which are used by 27 respondents (28.7\%), while 21 respondents (22.3\%) speak Italian. Russian is spoken by 17 respondents, French by 14 . Three 
ToSEE - Tourism in Southern and Eastern Europe, Vol. 6, pp. 455-466, 2021.

J. Miljković, T. Božović, I. Čapeta: COUCHSURFING AS A MODERN WAY OF DESTINATION ...

respondents each are fluent in Turkish and Hungarian, and other languages are less represented. Two respondents each speak Chinese, Swedish, Albanian, Romanian and Ruthenian. One respondent speaks Greek, Norwegian, Slovak, Esperanto, Macedonian and Slovenian.

Table 2: Languages spoken by respondents (percentages \%)

\begin{tabular}{cc}
\hline Country & Percentage (\%) \\
\hline English & $97.9 \%$ \\
German & $28.7 \%$ \\
Spanish & $28.7 \%$ \\
Italian & $22.3 \%$ \\
Russian & $18.1 \%$ \\
French & $14.9 \%$ \\
Turkish & $3.2 \%$ \\
Hungarian & $3.2 \%$ \\
Chinese & $2.1 \%$ \\
Swedish & $2.1 \%$ \\
Albanian & $2.1 \%$ \\
Romanian & $2.1 \%$ \\
Ruthenian & $2.1 \%$ \\
Greek & $1.1 \%$ \\
Slovak & $1.1 \%$ \\
Esperanto & $1.1 \%$ \\
Macedonian & $1.1 \%$ \\
Slovenian & $1.1 \%$ \\
\hline
\end{tabular}

Source: author's work

Traveling is a big part of contemporary life, a way to slow down the pace of life. Bearing in mind that travel is a way to relax and learn something new, the essential thing more often than not is to choose the right companion for the trip. Some prefer to travel alone, while some prefer to have someone join them - family, partner, friends. Table 3 shows the respondent's answers, with whom they choose to travel.

Table 3: Who do the respondents travel with?

\begin{tabular}{cc}
\hline Who do you travel with most often? & Percentage (\%) \\
\hline Family & 16.0 \\
Partner & 31.9 \\
Friends & 29.8 \\
Alone & 22.3 \\
\hline
\end{tabular}

Source: author's work

Respondents travel extensively with partners (31.9\%) or friends (29.8), and less with family (16\%). Based on the respondents' answers, it is noticeable that they generally prefer to travel in company, rather than alone. As Couchsurfing is a network intended for all travelers, the question is how the respondents who travel mostly alone experience this network, considering that safety and trust are a big part of the use. The category of respondents traveling alone $(22.3 \%)$ are mainly respondents from the age category 31 - 
ToSEE - Tourism in Southern and Eastern Europe, Vol. 6, pp. 455-466, 2021.

J. Miljković, T. Božović, I. Čapeta: COUCHSURFING AS A MODERN WAY OF DESTINATION ...

40 (10 respondents) and 21-30 (7 respondents). These are mainly male respondents (13 respondents). Educational structure of respondents traveling alone is almost the same (high school 8, faculty 7, master 6).

To understand the habits and aspirations of the respondents for using Couchsurfing while traveling, the authors divided the answers into three segments.

For the first segment, the results are shown in Table 4, which shows for how long the respondents have a profile on Couchsurfing and what is their current status of "couch" availability. Most respondents have a profile longer than six years (41.5\%), and the same number of users are in the category who have a profile less than two years and in the group 4-6 years (16\% each). In the 2-6 years group is $12.8 \%$ of the respondents. Respondents who are not sure how long they have had a profile are in a separate group, $13.8 \%$ of them.

Table 4: Couchsurfing Profile

\begin{tabular}{lccc}
\hline $\begin{array}{l}\text { How long have you had a } \\
\text { profile on CS? }\end{array}$ & Percentage $(\%)$ & $\begin{array}{c}\text { What is your current } \\
\text { profile status? }\end{array}$ & $\begin{array}{c}\text { Percentage } \\
(\%)\end{array}$ \\
\hline$<2$ years & 16.0 & Accepting guests & 10.6 \\
$2-4$ years & 12.8 & Maybe accepting guests & 33.0 \\
$4-6$ years & 16.0 & Not accepting guests & 31.9 \\
$>$ 6 years & 41.5 & Wants to meet up & 24.5 \\
Not sure & 13.8 & & \\
\hline
\end{tabular}

Source: author's work

In the second segment, the motives for registering and using Couchsurfing are shown, with situations in which the respondents decide to use the network.

As motivation is a large part of Couchsurfing users, Table 5 shows their motives to register on the network. The question was semi-open, where respondents could choose more than one offered answer and write down their motivation for using this network. Among the motives stands out the wish to get in touch with the locals at the destination they are traveling to (41 responses) followed by the motive to find „free“ accommodation during their stay (38 responses). To a lesser extent, the motive for registration was to host travelers (18 responses) and to show their place to travelers ( 24 responses). In addition to these respondents, another 25 respondents chose all the mentioned factors as their response. The motives for registering for Couchsurfing written by the respondents were curiosity about how the network works, a wish to find a company before or during the trip, as well as practice of a foreign language. Two respondents wrote that they could not single out any particular motive for registration. 
ToSEE - Tourism in Southern and Eastern Europe, Vol. 6, pp. 455-466, 2021.

J. Miljković, T. Božović, I. Čapeta: COUCHSURFING AS A MODERN WAY OF DESTINATION ...

Table 5: Motives for registering on the Couchsurfing network

\begin{tabular}{lcc}
\hline Motive & $\begin{array}{c}\text { Number of } \\
\text { answers }\end{array}$ & $\begin{array}{c}\text { Percentage of } \\
\text { Cases }(\%)\end{array}$ \\
\hline To host people who come to my place of residence & 18 & 19.1 \\
To get in touch with the locals at my destination & 41 & 43.6 \\
To have "free" accommodation for my travels & 38 & 40.4 \\
To show the city to the visitors as a local & 4 & 25.5 \\
All of the above. & 25 & 26.6 \\
I was interested in how the network works & 4 & 4.3 \\
To find company during the trip & 1 & 1.1 \\
To practice a foreign language & 1 & 1.1 \\
I can't single out a particular motive & 2 & 2.1 \\
\hline
\end{tabular}

Source: author's work

\subsection{Descriptive statistical analysis}

A group of respondents that travel alone was studied separately to discover the main reason for registering on the Couchsurfing network. Respondents pointed out as main motivation - the desire to get in touch with locals in the place where they travel (19/21 answers) and to have "free" accommodation (16/21 answers). An important motive is to show the city like a local to the passengers who come $(13 / 21)$ and to be the hosts $(10 / 21)$. Among the reasons was the interest in the functioning of the network, the desire to improve their knowledge of a foreign language, and to find a company at their destination.

In addition to the motivation, it was significant to find out in which situations respondents use Couchsurfing, whether it is during each trip, whether only when they travel alone, or still use more to host tourists and accommodate them in their home. It is noticeable that almost the same number of respondents use Couchsurfing both for traveling and as hosts.

Table 6: Situations in which respondents use Couchsurfing

\begin{tabular}{lr}
\hline & Percentage $(\%)$ \\
\hline For every trip & 11.7 \\
When I travel alone & 24.5 \\
To hang out with other hosts from my region & 2.1 \\
To meet the guests who come to my region & 26.6 \\
To accommodate travelers who come to my place & 12.8 \\
All of the above & 2.1 \\
To meet people during my travels & 3.2 \\
I registered to travel in a different way, but I no longer use it to that extent & 12.8 \\
As an escape from everyday life & 2.1 \\
To reduce travel costs & 1.1 \\
\hline
\end{tabular}

Source: author's work

Table 6 shows that it is a similar number of respondents use the network only for solo travels $(24.5 \%)$ and of those who want to meet tourists that come to their region $(26.6 \%)$. 
ToSEE - Tourism in Southern and Eastern Europe, Vol. 6, pp. 455-466, 2021.

J. Miljković, T. Božović, I. Čapeta: COUCHSURFING AS A MODERN WAY OF DESTINATION ...

In addition, $11.7 \%$ of the respondents use Couchsurfing for every trip, and $12.8 \%$ of the respondents use the network to offer accommodation to tourists who come to their place. Two respondents $(2.1 \%)$ said that they use Couchsurfing to meet and socialize with other hosts from their region, and also two respondents $(2.1 \%)$ pointed out that they use the network in all of the above situations. As this was also a semi-open question, respondents were able to write down the answers. Three respondents $(3.2 \%)$ use Couchsurfing to meet other people while traveling, two $(2.1 \%)$ use it as an escape from everyday situations, and one $(1.1 \%)$ respondent answered that it is in order to reduce travel costs. One part of the respondents, $12.8 \%$ wrote that they registered earlier when they traveled more, but they do not use it now to that extent.

\subsection{Trust in Couchsurfing}

In the third segment, two items were analyzed to determine the extent to which respondents consider the ratings of previous guests important when choosing a future host and how safe they think Couchsurfing is, all of which the respondents expressed on a Likert five-point scale (1 - I completely disagree, 2 - I partially disagree, 3 - I am not sure, 4 - I partially agree, 5 - I completely agree). Table 7 shows the results of the analysis.

In addition, the results of T-tests and ANOVA tests are presented, comparing different groups of respondents and their attitudes about Couchsurfing.

\section{Table 7: Trust in Couchsurfing}

\begin{tabular}{lcc}
\hline Factor & Mean & Standard deviation \\
\hline „Couchsurfing is safe“ & 4.05 & .739 \\
"When choosing a potential & 4.39 & .918 \\
host, I pay attention to the & & \\
reviews of previous guests" & & \\
\hline
\end{tabular}

Source: author's work

Descriptive statistical analysis was conducted in order to determine the importance of safety and trust in Couchsurfing. Both factors are presented in the previous table separately, through mean values and standard deviations for each statement. Both factors have a value above 4 , which shows that respondents still believe that Couchsurfing is safe, and that the ratings of previous guests when selecting potential hosts are of great importance. This proves that respondents extensively trust the ratings on Couchsurfing and that it is also an effective method to gain trust online.

\subsection{T-Test}

T-test was performed to determine potential differences in responses between men and women. 
ToSEE - Tourism in Southern and Eastern Europe, Vol. 6, pp. 455-466, 2021.

J. Miljković, T. Božović, I. Čapeta: COUCHSURFING AS A MODERN WAY OF DESTINATION ...

The T-Test of Independent Samples compared the results of an examination of the attitude "Couchsurfing is safe" and the results showed that there is a statistically significant difference in the responses of men and women $(\mathrm{t}=-1.388 ; \mathrm{p}=0.008)$, where men are more likely to think Couchsurfing is safe.

Analysis of the results for the statement "When looking for a potential host, I pay attention to the ratings of previous guests" showed that there is no statistically significant difference between the responses of men and women.

\subsection{ANOVA test}

One-way analysis of variance calculation (ANOVA test) was done based on two factors - "Couchsurfing is safe" and "When choosing a potential host, I pay attention to the reviews of previous guests". Factors were compared according to the following variables: Age; Education; Revenues; Who do the respondents travel with; How long have they had a profile on Couchsurfing. Of all the analyzes, the only analysis that showed statistically significant differences is in what relation the respondents from different age categories believe that the ratings of previous guests are important when choosing a host $(\mathrm{F}=2.904 ; \mathrm{p}=0.018)$. The difference is noticeable between the categories $<20$ years, with the categories $21-30 ; 31-40 ; 41-50$; where the respondents from the category $<20$ years of age believe that the ratings of previous guests are not so important when choosing a host. As a potential reason for obtaining this result and this difference, the reason may be that only two respondents, out of the total number, are from the age category $<20$. Among other categories, there is no statistically significant difference concerning the given factors.

\section{CONCLUSION}

Over the past year, the ways of traveling and destinations themselves have changed significantly. The health component of travel became the most important, and it was virtually impossible to use the social network Couchsurfing to the previous extent. All this has led to a reduced number of active users online and aggravated getting answers to the survey. Users with whom the authors came in contact via private messages on Couchsurfing confirmed these facts. However, the motivation for using the network in future trips is not missing for a substantial part of the respondents. As Liu (2012) specified that the motivation for using this network is to get in touch with the local population while traveling and to find company at the destination, the authors confirmed these motives in a sample of respondents from former Yugoslav countries. This research opened the topic of using Couchsurfing in the targeted group and it is the basis for further research by increasing the sample. It can be concluded that the respondents believe that Couchsurfing is safe, while emphasizing that it is necessary to gain trust in a potential host, and the reviews on the profiles are the first step towards that.

\section{ACKNOWLEDGMENT}

Ministry of Education, Science and Technological Development of the Republic of Serbia supported this research. 
ToSEE - Tourism in Southern and Eastern Europe, Vol. 6, pp. 455-466, 2021.

J. Miljković, T. Božović, I. Čapeta: COUCHSURFING AS A MODERN WAY OF DESTINATION ...

\section{REFERENCES}

Bialski, P. (2012), "Technologies of hospitality: How planned encounters develop between strangers", Hospitality \& Society, Vol. 1, No. 3, pp. 245-260. https://doi.org/10.1386/hosp.1.3.245_1

Bialski, P. and Batorski, D. (2010), From online familiarity to offline trust: How a virtual community creates familiarity and trust between strangers, Social computing and virtual communities, (Chapter 8), pp.179-204.

Chen, D.J. (2018), “Couchsurfing: Performing the travel style through hospitality exchange”, Tourist studies, Vol. 18, No. 1, pp.105-122. https://doi.org/10.1177/1468797617710597

Dickinson, J., and Lumsdon, L. (2010), Slow Travel and Tourism, Earthscan, London.

Fullagar, S., Markwell, K. and Wilson, E. (Eds.) (2012), Slow Tourism: Experiences and Mobilities, Channel View Publications, Bristol.

Gardner, N. (2009), "A Manifesto for Slow Travel. Hidden Europe", available at: http://www.hiddeneurope.co.uk/a-manifesto-for-slow-travel

Georgica, G. (2015), "The Tourist's Perception about Slow Travel-A Romanian Perspective", Procedia Economics and Finance, Vol. 23, pp.1596-1601. https://doi.org/10.1016/S2212-5671(15)00557-2

Glas, D.F., Wada, K., Shiomi, M., Kanda, T., Ishiguro, H. and Hagita, N. (2017), "Personal greetings: Personalizing robot utterances based on novelty of observed behavior", International Journal of Social Robotics, Vol. 9, No. 2, pp.181-198. https://doi.org/10.1007/s12369-016-0385-4

Lipp, R. (2012), Cosmopolitan Relationships in CouchSurfing: an explorative analysis of a Web 2.0 platform, Universität Bamberg.

Liu, J. (2012), The intimate stranger on your couch: An analysis of motivation, presentation and trust through Couchsurfing, Master's thesis, Department of Informatics and Media, Uppsala University.

Mijatov, M.B. and Pivac, T. (2016), CouchSurfing as a modern trend in tourism, Poslovna ekonomija, Vol. 10, No. 1, pp.190-217.

Molz, J.G. (2009), "Representing Place in Tourism Mobilities: Staycations, Slow Travel and the Amazing Race", Journal of Tourism and Cultural Change, Vol. 7, pp. 270-286.

Molz, J.G. (2012), "CouchSurfing and network hospitality:'It's not just about the furniture'”, Hospitality \& Society, Vol. 1, No. 3, pp. 215-225. doi: 10.1386/hosp.1.3.215_2

Neuburger, L. and Egger, R. (2020), "Travel risk perception and travel behaviour during the COVID-19 pandemic 2020: a case study of the DACH region", Current Issues in Tourism, pp. 1-14. https://doi.org/10.1080/13683500.2020.1803807

O'Reilly, T. (2007), "What is Web 2.0: Design patterns and business models for the next generation of software", Communications \& strategies, No. 1, pp. 17-37.

Ronzhyn, A. and Kuznetsova, E. (2014), "Conveying the message of trust through written texts in Couchsurfing. org.", Synthesis: an Anglophone Journal of Comparative Literary Studies, No. 6, pp 92-111. https://doi.org/10.12681/syn.16179

Ronzhyn, O. (2015), Trust and tolerance in online hospitality networks, Doctoral dissertation, Universidad de Deusto.

Rosen, D., Lafontaine, P.R. and Hendrickson, B. (2011), "CouchSurfing: Belonging and trust in a globally cooperative online social network", New Media \& Society, Vol. 13, No. 6, pp. 981-998. https://doi.org/10.1177/1461444810390341

Sigala, M. (2020), "Tourism and COVID-19: Impacts and implications for advancing and resetting industry and research", Journal of business research, Vol. 117, pp. 312-321. doi:10.1016/j.jbusres.2020.06.015

Skog, C., 2012. Couchsurfing-a choice for travellers, Bachelor's Thesis, HAAGA-HELIA University of Applied Sciences.

Taheri, B., Hosany, S. and Altinay, L. (2019), "Consumer engagement in the tourism industry: new trends and implications for research", Service Industries Journal, Vol. 39, No. 7-8, pp. 463-468 https://doi.org/10.1080/02642069.2019.1595374

Tan, J.E. (2010), "The leap of faith from online to offline: An exploratory study of Couchsurfing. org.", in International Conference on Trust and Trustworthy Computing, Springer, Berlin, Heidelberg, pp. 367-380. https://doi.org/10.1007/978-3-642-13869-0_27

Uzunca, B. and Borlenghi, A. (2019)," Regulation strictness and supply in the platform economy: the case of Airbnb and Couchsurfing", Industry and Innovation, Vol. 26, No. 8, pp. 920-942. doi: 10.1080/13662716.2019.1633278

Wolff, K., Larsen, S. and Øgaard, T. (2019), "How to define and measure risk perceptions", Annals of Tourism Research, Vol. 79, 102759. https://doi.org/10.1016/j.annals.2019.102759 
ToSEE - Tourism in Southern and Eastern Europe, Vol. 6, pp. 455-466, 2021.

J. Miljković, T. Božović, I. Čapeta: COUCHSURFING AS A MODERN WAY OF DESTINATION ...

Jovana Miljković, MsC, PhD student

University of Novi Sad, Faculty of Natural Sciences

Department of Geography, Tourism and Hotel Management

Dositej Obradovic Square 3, Novi Sad, Serbia

+381628590208

miljkovic.jovana.95@gmail.com

Tamara Božović, MsC, Phd Student

University of Novi Sad, Faculty of Natural Sciences

Department of Geography, Tourism and Hotel Management

Dositej Obradovic Square 3, Novi Sad, Serbia

+381669160091

tamaraabozovic@gmail.com

Ivan Čapeta,

University or Rijeka, Faculty of Tourism and Hospitality Management Department for Business economy in Tourism and Hospitality Industry Primorska 46, 51410 Opatija, Croatia

+385997310232

capeta.ivan@hotmail.com 